\title{
„Tam jest życie, a tu już jakby nie-życie” Z Piotrem Pazińskim o hebrajskiej literaturze Zagłady rozmawiają Jagoda Budzik i Bartłomiej Krupa
}

Bartłomiej Krupa: Nie ukrywam, że zafrapowało nas unikanie przez Ciebie tematu. W mailu użyłeś szeregu argumentów, dlaczego nie zajmujesz się literaturą izraelską dotyczącą Zagłady. I to nas szczególnie zaciekawiło, ale może zacznijmy od takiego ogólniejszego pytania o Twoje doświadczenia z literaturą hebrajską w ogóle. Jak to się zaczęło? Jak doszedłeś do Szmuela Agnona ${ }^{1}$ ?

Piotr Paziński: Moje doświadczenia z literaturą hebrajską? Nie znam bardzo dobrze całej literatury hebrajskiej, raczej jej fragmenty. Nigdy systematycznie nie studiowałem hebraistyki. Hebrajski znam, owszem, z kilkuletniego kursu w Polsce i kilkudziesięciu pobytów w Izraelu, dłuższych i krótszych, oraz okresu mieszkania tam. Jest to więc bardzo niesystematyczne.

Moje spotkania z literaturą hebrajską były początkowo - tak jak w przypadku wielu osób w Polsce - przez język polski. Myślę, że nadal więcej literatury hebrajskiej przeczytałem po polsku czy po angielsku niż po hebrajsku. To już kwestia ułatwienia sobie życia. Pewnie były to początkowo spotkania, w okresie późnonastoletnim, z takimi pisarzami, którzy pojawiali się w Polsce wtedy, kiedy jeszcze hebrajskiego nie znałem lub znałem elementarnie, czyli pewnie z Amosem $\mathrm{Ozem}^{2}$ i towarzyszącą mu konstelacją. Nie pamiętam, kiedy przeczytałem

\footnotetext{
${ }^{1}$ Piotr Paziński jest autorem wyboru i tłumaczem zbioru opowiadań Szmuela Josefa Agnona Przypowieść o skrybie i inne opowiadania, który ukazał się w 2016 r. w Wydawnictwie Nisza. Por. notkę biograficzną Agnona w przyp. 19.

2 Amos Oz (1939-2018) - izraelski pisarz i wykładowca literatury na Uniwersytecie w Beer Szewie. Pierwsze jego książki ukazywały się w Polsce w pierwszej połowie lat 90. w tłumacze-
} 
Roman Rusi, czyli Rosyjski romans Meira Szalewa ${ }^{3}$, który był dość wcześnie przetłumaczony i potem wznowiony ${ }^{4}$. Poznałem trochę autorów polskich piszących w Izraelu, natomiast chyba tak systematycznie literaturę hebrajską zacząłem czytać później - bo ja wiem - w drugiej połowie lat 90. To, co się ukazywało w Polsce, i w związku z tym to, co mogłem przeczytać albo, zainteresowawszy się, po polsku, albo po angielsku i potem mogłem czytać po hebrajsku. Na przykład Abrahama B. Jehoszuę ${ }^{5}$, Dawida Grossmana ${ }^{6}$, Szalewa, Ceruję Szalew, jak się pojawiła, a pojawiła się w sumie dosyć późno, jako pisarka - i tam, i tu' ${ }^{7}$. Etgara Kereta $^{8}$, którego pamiętam jako autora zupełnie świeżego, chłopaka, który przyjechał do Warszawy bodaj w dziewięćdziesiątym piątym czy szóstym roku na festiwal Świata Literackiego. Wtedy ukazał się pierwszy jego tomik, który wówczas wydawał mi się czymś niezwykle świeżym9. Opowiadanie o butach zrobionych ze skóry dziadka zamordowanego podczas Zagłady i o kotku, który się nazywał Rabin - to było tuż po zabójstwie Icchaka Rabina ${ }^{10}$. Potem opowiadanie Pizzeria

niach z języka angielskiego nakładem Czytelnika: Mój Michał (1968, pol. 1991), oraz Niezależnej Oficyny Wydawniczej: Czarna skrzynka (1987, pol. 1995) i Na ziemi Izraela (1982, pol. 1996). Pierwszą powieścią przełożoną bezpośrednio z hebrajskiego była Poznać kobietę (1989, pol. 1995) w tłumaczeniu Ewy Świderskiej. Z hebrajskiego oryginału na polski przekładał Oza również Leszek Kwiatkowski.

${ }^{3}$ Meir Szalew (ur. 1948) - izraelski pisarz, redaktor programów radiowych i telewizyjnych. $\mathrm{Z}$ wykształcenia psycholog. Autor licznych książek dla dzieci, znany też jako komentator społeczny.

${ }^{4}$ Zob. M. Shalev: Rosyjski romans. Przeł. z hebr. R. Bar-Peled. Warszawa: „Sic!”, 1993 (wyd. II - Muza, 2010). W rozmowie celowo podano nazwy wydawnictw, które w Polsce wydają literaturę izraelską.

${ }^{5}$ Abraham B. Jehoszua (ur. 1936) - pisarz, profesor Uniwersytatu w Hajfie. Po polsku ukazały się m.in. w tłumaczeniu L. Kwiatkowskiego jego powieści Powrót $z$ Indii (1996, pol. 2005) i Pan Mani (1990, pol. 2008) oraz w przekładzie Magdaleny Sommer Kochanek (1979, pol. 2005).

${ }^{6}$ Dawid Grossman (ur. 1954) - pisarz izraelski, absolwent filozofii i wiedzy o teatrze na Uniwersytecie Hebrajskim. Autor tłumaczonych na wiele języków powieści i książek dla dzieci. Przez wiele lat pracował w Radiu Izraelskim, zwolennik porozumienia między Żydami i Palestyńczykami.

7 Ceruja Szalew lub Zeruya Shalev (ur. 1959) - najczęściej obecnie tłumaczona pisarka izraelska. W Polsce ukazały się cztery jej książki, nakładem Wydawnictwa W.A.B., w tłumaczeniu M. Sommer i Agnieszki Jawor-Polak: Życie miłosne (2003), Mąż i żona (2004), Po rozstaniu (2008) i Ból (2017).

${ }^{8}$ Etgar Keret (ur. 1967) - izraelsko-polski pisarz, poeta, felietonista i reżyser, wykładowca Wyższej Szkoły Filmowej w Tel Awiwie. Znany głównie ze zbiorów krótkich opowiadań: Rury (1992, pol. 2007), Tęskniąc za Kissingerem (1994, pol. 2008) i następnych. W Polsce ukazują się one głównie w tłumaczeniu Agnieszki Maciejowskiej.

${ }_{9}$ Mowa zapewne o zbiorze Gaza blues, który jako pierwszy ukazał się w Polsce („Świat Literacki”, 2000). Debiutancki tom Kereta Tzinorot (1992) został wydany jako Rury później, nakładem W.A.B., w 2007 r. Oba w tłumaczeniu A. Maciejowskiej.

${ }^{10}$ Chodzi o opowiadanie Buty z tomu Tęskniąc za Kissingerem (1994, pol. 2008) oraz Rabin umart z tomu Hakajtana Szel Kneller (1998, po pol. w tomie $8 \%$ z niczego z 2006). Oba w tłumaczeniu A. Maciejowskiej. Icchak Rabin (1922-1995) - generał, szef Sztabu Generalnego Sił 
„Kamikaze” o zaświatach, w których izraelscy samobójcy i palestyńscy zamachowcy żyją sobie wspólnie ${ }^{11}$ - to wydawało się wtedy bardzo na czasie. Potem Keret mi się trochę znudził, bo stał się - chcąc nie chcąc - ambasadorem całej kultury izraelskiej w Polsce, zamęczanym w kolejnych wywiadach i wyborach opowiadań. Niekiedy się wydawało, że on „robi” za całą literaturę izraelską - i za sumienie Izraela, i za umysł Izraela, i za literaturę Izraela. To się zrobiło bardzo męczące.

W pewnym momencie odkryłem Aharona Appelfelda ${ }^{12}$, który mi się bardzo podobał. Niektóre jego rzeczy. Zobaczyłem wtedy, że literatura hebrajska jest także niekiedy literaturą zagładową - to Mesilat barzel, czyli Droga żelazna ale też zahaczającą o takie rejony dla mnie bardzo interesujące w Europie, czyli na przykład Czerniowce, Bukowinę, tamtejszą wielojęzyczność. Appelfeld jest autorem na przykład bardzo ciekawych pamiętników ${ }^{13}$, z których wynika, że on w zasadzie wyszedł z wojny jako prawie analfabeta znający wiele języków mówionych. Hebrajski był jego pierwszym językiem literackim. Niesamowita historia. Wyrosnąć z tygla językowego, a zacząć pisać jeszcze w innym. Ten pisarz jest więc odnóżką europejską w Izraelu, zresztą Ost-europejskość jakoś eksploruje. Dlatego też A.B. Jehoszua wydał mi się ciekawy, bo jest zupełnie inny. To jest człowiek, który nie pochodzi z Europy, jest dziedzicem świata sefardyjskiego, ale urodził się już w Jerozolimie. Podobała mi się pięcioczłonowa powieść Pan Mani, która ukazała się w Polsce ${ }^{14}$. Inne były różne. Lubię wczesne opowiadania Jehoszui, nietłumaczone. Czytałem je po hebrajsku, pomieszczone w tomach $\mathrm{z}$ lat $60{ }^{15}$ - ostentacyjnie świeckie, izraelskie, bardzo fajne. A to o dziwnej linii kolejowej, która idzie przez pustynię, a to o zagubionym na pustyni oddziale żołnierzy - właśnie je przetłumaczyłem ${ }^{16}$. Nazywa się Ostatni dowódca i jest

Obronnych i dwukrotny premier Izraela (1974-1977 i 1992-1995). Laureat Pokojowej Nagrody Nobla w 1994 r., razem z Jasirem Arafatem i Szymonem Peresem. W dniu 4 listopada 1995 r., po zakończeniu pokojowego wiecu na placu Królów Izraela w Tel Awiwie (dziś plac Rabina), został postrzelony przez żydowskiego nacjonalistę Jigala Amira. Zmarł dwie godziny później.

${ }^{11}$ Opowiadanie Pizzeria "Kamikaze” ukazało się w Polsce, wydane przez „Świat Literacki”, pod takim samym tytułem (2001). W 2004 r. opublikowano je też w Izraelu jako powieść graficzną z rysunkami Asafa Hanuki.

${ }^{12}$ Aharon (właśc. Erwin) Appelfeld (1932-2018) - prozaik i poeta izraelski, pochodzący z Czerniowców, wówczas w Królestwie Rumunii. Po polsku ukazały się jego powieści: Badenheim 1939 (1979, pol. 2004, przeł. Henryk Szafir) oraz Droga żelazna (1991, pol. 2006, przeł. Anna Volovici).

${ }^{13}$ Pamiętniki Appelfelda Sipur chaim (1999) - 'historia życia', tłum. na ang. jako The Story of a Life. A memoir (2003, transl. Aloma Halter) - nie ukazały się dotąd po polsku.

${ }_{14}$ A.B. Jehoszua: Pan Mani [Mar Mani, 1990]. Przeł. L. Kwiatkowski. Warszawa: Cyklady, 2008.

${ }^{15}$ Zapewne chodzi o tom Mot ha-zaken („Śmierć starego człowieka”) z 1962 r. Wcześniej, pod koniec lat 50., Jehoszua pisał dla gazety „Lamerhaw” i periodyku „Keszet”.

${ }^{16}$ Mowa o opowiadaniu Hamefaked ha-aharon (Ostatni dowódca), opublikowanym we wspomnianym zbiorze Mot ha-zaken (1962). Tłumaczenie tego tekstu ukazało się w „Li- 
rozrachunkiem z wojną synajską ${ }^{17}$, nawiązuje do poematu Metej midbar, czyli „Umarli pustyni”, Chajima Nachmana Bialika ${ }^{18}$ i do Księgi Wyjścia.

W którymś momencie pojawił się Agnon ${ }^{19}$. I na pewno - tu nie będę ściemniał - najpierw się pojawił po polsku, potem po angielsku, później grzecznie przeczytałem ponownie bardzo wiele rzeczy Agnona po hebrajsku i zacząłem go sobie tłumaczyć. Słyszałem zawsze od różnych kuzynów i znajomych w Izraelu, że to takie potwornie trudne. Albo tego w ogóle nie czytali, albo mówili, że nie do przeczytania, albo że jest tak strasznie trudne, że nic z tego nie rozumieją, a tak naprawdę nikt tego nie czytał, poza dwoma opowiadaniami. I rzeczywiście muszę powiedzieć, że mało znam osób, które przeczytały utwory Agnona, zarówno świeckich, jak i religijnych Izraelczyków. Żałuję, że nie mogłem o nim porozmawiać z moim wujem, który był dla mnie w pewnym sensie wyrocznią, człowiekiem religijnym i jednocześnie intelektualistą pierwszego pokolenia ojców założycieli państwa. Przede wszystkim znał go osobiście, a też mógł czytać. Był z tego pokolenia, które miało w głowie całą bibliotekę tradycyjnych, żydowskich tekstów, a jednocześnie czytało literaturę. Teraz mam wrażenie, że to się bardzo dramatycznie rozszczepiło, o czym Amos Oz i jego córka Fania Salzberger napisali książkę, którą sam zresztą tłumaczyłem z angielskiego, bo ona była pisana po angielsku ${ }^{20}$.

\section{B.K.: Żydzi i słowa?}

P.P.: Tak, Żydzi i słowa są o tym rozłamie - że religijni już nie czytają świeckich książek, a świeccy nie mają żadnego - często - zaplecza religijnego poza lekcjami Tanachu $^{21}$ w podstawówce. W związku z tym Agnona też nie są w stanie przeczytać i staje się on pisarzem dla pięciu osób.

teraturze na Świecie" już po odbyciu tej rozmowy. Zob. A.B. Jehoszua: Ostatni dowódca. Przeł. P. PAziński. „Literatura na Świecie” 2018, nr 9-10, s. 213-233.

${ }^{17}$ Wojna synajska - jedno z określeń tzw. wojny sześciodniowej z 1956 r. Inne nazwy to m.in.: II wojna izraelsko-arabska, wojna Suez-Synaj, kampania sueska, operacja „Kadesz” czy „potrójna agresja”.

${ }^{18}$ Chajim Nachman Bialik (1873-1934) - uważany za narodowego poetę izraelskiego i „odnowiciela poezji hebrajskiej”. Tworzył w języku hebrajskim oraz jidysz. Także tłumacz, eseista i wydawca. Urodzony pod Żytomierzem na Wołyniu, mieszkał później w Odessie, pod Kijowem, w Sosnowcu i Berlinie, by ostatnie 10 lat życia spędzić w Tel Awiwie, gdzie w jego dawnym domu mieści się teraz muzeum.

${ }^{19}$ Szmuel Josef Agnon (1888-1970) - hebrajski pisarz, uczony i badacz tradycji. Laureat Nagrody Nobla w dziedzinie literatury za $1966 \mathrm{r}$.

20 A. Oz, F. Oz-Salzberger: Jews and Words. New Haven: Yale University Press, 2012; Ciż: Żydzi i słowa. Przeł. P. PAzıński. Warszawa: Czytelnik, 2014.

${ }^{21}$ Tanach - Biblia hebrajska, akronim utworzony od początkowych liter trzech części Pisma: Tora (Pięcioksiąg, czyli Prawo), Newiim (Prorocy) i Ketuwim (Pisma). 
B.K.: W jego przypadku ciekawe są także aspekty językowe. Świecka hebrajszczyzna jest w jakiejś mierze językiem Agnona. Chyba mało który pisarz wywarł tak wielki wpływ na rozwój języka? W takim sensie, że Izraelczycy z lat, powiedzmy, 40. i 50. „mówili Agnonem”?

P.P.: To nie jest takie proste. Wydaje mi się, że to trzeba skomplikować. Agnonem rzeczywiście mówili ci Izraelczycy, którzy jednocześnie bywali religijnymi Żydami, intelektualistami, którzy wyszli z midraszy, z jesziwy i stali się ludźmi świeckimi. Jednocześnie jego język już w latach 40. był postrzegany jako staroświecki, zbyt kwiecisty, zbyt bogaty, zbyt religiancki.

Jagoda Budzik: Chyba też zbyt diasporowy?

P.P.: I zbyt diasporowy! Bialik też był diasporowy, ale to był człowiek, którego poematów uczono się na pamięć. Na nim uczono się hebrajskiego, był w lekturach jeszcze w czasach jiszuwu i w diasporze przed wojną. W Gimnazjum Herzlija $^{22}$, w gimnazjach Tarbutu ${ }^{23}$ uczono się Bialika, nie Agnona. Uczono się Saula Czernichowskiego, nie Agnona. Uczono się wielu różnych rzeczy, na przykład hebrajskiej moderny, Uriego Gnesina ${ }^{24}$, Josefa Chaima Brennera ${ }^{25}$ i innych. Uczono się tego w narzeczach pohaskalowych, Biblii i Bialika. Agnon stał gdzieś z boku. W gruncie rzeczy cały czas był pisarzem dla elity, ale ta elita była wówczas niezmiernie ważna, bo budowała Państwo Izrael i wszystko, co wokół, to on też był ważny. Jak weźmiemy klasyczny słownik Abrahama Ewen-Szoszana ${ }^{26}$, najważniejszego izraelskiego leksykografa, współtwórcy i kodyfikatora dwudziestowiecznej hebrajszczyzny, to znajdziemy setki odwołań do Agnona i Bialika. Ewen-Szoszan wywodził się zresztą z bardzo podobnego środowiska, odebrał tradycyjne rabiniczne wykształcenie w jesziwie i miał w głowie całą bibliotekę

${ }^{22}$ Gimnazjum Herzlija - szkoła w Tel Awiwie, powstała w 1905 r. i była pierwszą hebrajską szkołą średnią.

${ }^{23}$ Tarbut - Żydowskie Stowarzyszenie Oświatowo-Kulturalne, działające pod auspicjami Organizacji Syjonistycznej. Pod koniec lat 20. funkcjonowało w ok. 300 miastach Polski, Rumunii, Litwy, Bułgarii i Wielkiej Brytanii, prowadząc m.in. przedszkola i szkoły.

${ }^{24}$ Uri Nisan Gnesin (1881-1913) - pisarz żydowski, twórca prozy psychologicznej, wykorzystującej np. strumień świadomości. Wywarł duży wpływ na rozwój literatury hebrajskiej.

${ }^{25}$ Josef Chaim Brenner (1881-1921) - żydowski pisarz i publicysta, tworzący w języku hebrajskim. Od 1904 r. przebywał w Londynie, potem rok we Lwowie, wreszcie od 1909 r. w Palestynie. W swojej twórczości opisywał rozterki duchowe i intelektualne młodego Żyda żyjącego w społeczeństwie pozbawionym tradycyjnych wartości i celu życia. Był autorem licznych opowiadań: Ba-choref („W zimie”, 1903), Mi-kan u-mi-kan („Stąd i stamtąd”, 1911) czy Szechol we-chiszalon („Ogołocenie i klęska”, 1920). Przełożył na język hebrajski m.in. Zbrodnię i karę Fiodora Dostojewskiego.

${ }^{26}$ Słownik stworzony przez urodzonego w Mińsku leksykografa Abrahama Ewen-Szoszana (1906-1984), po raz pierwszy opublikowany w latach 1948-1952 jako Milon Hadasz („Nowy słownik"). 
tekstów. Z niej robił język. Nie ma już takich ludzi. Albo znasz całą literaturę rabiniczną, ale najczęściej już nie czytałeś nic świeckiego, poza lekturami szkolnymi, albo już niestety nie masz literatury rabinicznej i zostajesz tak naprawdę w próżni. Odniesieniem jest przerabiany w świeckiej szkole Tanach oraz Amos $\mathrm{Oz}$, pomiędzy nic nie ma.

B.K.: Ciekawe jest to, na co zwróciłeś uwagę w czasie naszego seminarium Zespołu Badań nad Literaturą Zagłady ${ }^{27}$ - że interesująca może być religijna proza dotycząca Zagłady.

P.P.: Ale mówiłaś, że to akurat jest niedobra powieść, ten Powrót $t^{28}$ ?

J.B.: Ona jest niedobra również ze względu na to, że nie wyczerpuje wszystkich możliwości, jakie daje pomysł tworzenia alternatywnej historii. I jest też niedobra dlatego, że ideologiczne podłoże, wyraźnie syjonistyczne, dominuje nad bardziej złożoną wizją sytuacji. Jeśli chodzi o religijną literaturę - choć właściwie nie wiem, czy klasyfikowałabym ją jako religijną literaturę, to jest na pewno literatura religijnego autora - to gdy pomyślimy o wcześniejszych tekstach, które powstawały w Izraelu zaraz po wojnie czy w pierwszych dekadach, możliwe, że tam faktycznie znalazłoby się coś ciekawego.

B.K.: Właśnie, tylko nikt się na tym nie zna. Mnie na przykład, jako człowieka świeckiego, nigdy to nie interesowało.

J.B.: To też pytanie, w jakim stopniu było możliwe, aby takie rzeczy mogły powstawać po hebrajsku. To bardzo ważne, na co zwróciłeś uwagę na seminarium.

P.P.: Trzeba by zapytać kogoś, kto jak Gabriel Moked ${ }^{29}$ przeczytał każdą książkę. Być może on zna i podrzuci przykład jakiegoś nieznanego, drugorzędnego pisarza izraelskiego, który był religijny jednocześnie.

J.B.: Jeśli myślimy o tych powojennych dekadach, to wybór języka był bardzo mocną, ideologiczną deklaracją. $\mathrm{Z}$ jednej strony wynikało to $\mathrm{z}$ takich podsta-

${ }^{27}$ Mowa o seminarium Zespołu Badań nad Literaturą Zagłady IBL PAN 28 listopada 2017 r., na którym Jagoda Budzik prezentowała referat „Izraelscy autorzy trzeciego pokolenia: między instytucjonalnym dyskursem o Zagładzie a wizją Polski”. Zob. nagranie: http://literaturazaglady. ibl.waw.pl/sem_28_11_2017.html [data dostępu: 05.07.2018].

${ }^{28}$ Chodzi o powieść Tel Awiw Jaira Chasdiela, która traktuje o powrocie Żyda do Polski. Tom ten omawia Jagoda Budzik na wspomnianym seminarium.

${ }^{29}$ Gabriel Moked (ur. 1933) - literaturoznawca i filozof, urodzony w Warszawie, przebywał w getcie warszawskim. Po wojnie wyjechał do Izraela. Doktorat uzyskał w Oxfordzie, jest profesorem filozofii na Uniwersytecie Ben-Guriona, a ponadto redaktorem czasopism literackich "The Jerusalem Review” oraz hebrajskiego „Achszaw”. 
wowych kwestii, jak ta, że większość autorów jeszcze nie znała hebrajskiego na tyle dobrze, by pisać literaturę, a z drugiej - budowanie hebrajszczyzny było też budowaniem państwa, co mogło wpływać na to, że do opowiadania o Zagładzie wybierano inne języki. Jakie są Twoim zdaniem najistotniejsze powody tego, że Szoa nie była obecna w tym mainstreamowym, hebrajskim kanonie pierwszych dekad?

P.P.: Jeden powód jest na pewno taki, że większość - na pewno nie wszyscy ludzi, którzy ten kanon tworzyli w latach 40., 50. i 60., to byli native speakerzy. Jeśli nawet się nie urodzili w Izraelu czy Mandacie Palestyny, to przyjechali jako kilkulatkowie - Haim $\mathrm{Hazaz}^{30}$, później Oz, Joram Kaniuk ${ }^{31}$, który pisał jednak o Zagładzie, Jehoszua - to są ludzie, którzy są stamtąd i w związku z tym Szoa nie widzieli i się $\mathrm{z}$ nią nie zetknęli. To trochę takie pytanie, jak to, dlaczego Saul Bellow nie jest pisarzem Holokaustu, czy nawet Philip Roth, czy Bernard Malamud. Nie są, bo są stamtąd i o czym innym piszą. Tutaj musielibyśmy znaleźć kogoś, kto przyjeżdża na przykład do Izraela w 1946, w 1947 roku i bardzo szybko zaczyna pisać po hebrajsku, i jednocześnie pisze o Zagładzie. Pytanie: czy ktoś taki jest? Poza wybitnym Aharonem Appelfeldem, który znowuż nigdy tak naprawdę nie zajął się pisaniem o Izraelu, całe swoje izraelskie życie poświęcił pisaniu o diasporze i jej katastrofie.

B.K.: Polskojęzyczni niektórzy. Miriam Akavia trafia przecież do Palestyny tuż po wojnie i pisze również po hebrajsku.

P.P.: Miriam Akavia, Irit Amiel pisały po hebrajsku i po polsku. Irit Amiel napisała po polsku swoje najlepsze teksty. Tyle że trudno o nich powiedzieć, że należały do głównego nurtu literatury izraelskiej.

B.K.: Właśnie, o to chodzi!

P.P.: Przynajmniej do procesu Eichmanna Zagłada nie jest ważnym problemem. Problemem jest wojna o niepodległość i budowanie państwa. Agnon zostaje noblistą i tym samym ojcem założycielem, patronem literatury hebrajskiej, choć przecież już w latach 30. zarzuca się mu, że nie włącza się konstruktywnie w życie kraju i jest ostentacyjnie staroświecki. O czym on pisze? W 1939 roku

${ }^{30}$ Haim Hazaz (1898-1973) - urodzony na Ukrainie pisarz izraelski, który w latach 20. przyłączył się do ruchu syjonistycznego. Osiedlił się w Jerozolimie w 1933 r., stając się jednym z najbardziej wpływowych prozaików w Izraelu.

${ }^{31}$ Joram Kaniuk (1930-2013) - izraelski pisarz, malarz, dziennikarz i krytyk teatralny. Urodzony w Tel Awiwie, brał udział w wojnie o niepodległość, w czasie której został ciężko ranny. Hospitalizowany w USA wrócił do Izraela dopiero w 1958 r. Był autorem 17 powieści, licznych esejów i opowiadań, tłumaczonych na wiele języków. 
rzuca wielką powieść o Buczaczu ${ }^{32}$, wcześniej przez prawie dwadzieścia lat pisze legendy chasydzkie. Dopiero jego trzecia powieść - Tmol szilszom, czyli „Zaledwie wczoraj”, z 1945 roku, jest powieścią o drugiej aliji. Ale nie napisał słowa na przykład o wojnie o niepodległość. To robią ludzie o czterdzieści lat młodsi od niego, tzw. pokolenie Kraju (dor haArec) albo pokolenie Palmachu (uczestnicy wojny o niepodległość), zupełnie w Polsce nieznani twórcy realistycznej i zaangażowanej prozy, przez swoją schematyczność niekiedy porównywanej do socrealizmu. Kolejne pokolenie, tzw. pokolenie państwa (dor ha medina), zna wojnę z dzieciństwa, w dorosłość wchodzi w latach 50. i zajmuje się krajem, sytuacją społeczną, wojskiem, wojną, kibucem, Arabami. Amos Oz pisze wprawdzie o ostatnich latach Mandatu Palestyny, ale przedstawia to oczami dziecka. Ta bitna Jerozolima, zapyziała, mała, pełna emigrantów i Arabów, którzy są czymś zupełnie niezrozumiałym, obcym, dziwnym i innym. Zagłada to depresja matki, która traci całą rodzinę w Równem i nie umie się z tym pogodzić. Być może Opowieść o miłości i mroku to najważniejsza izraelska książka o Zagładzie ${ }^{33}$, o pozagładowej depresji, o cieniu, jaki Zagłada rzuca na izraelskie życie. A nie Ajen erekh-ahawah (1986), czyli Patrz pod: Miłość (2008) Dawida Grossmana.

B.K.: Właśnie, o Grossmana też chcieliśmy spytać.

P.P.: Bardzo go polubiłem prywatnie. Prowadziłem z nim spotkanie trzy lata temu we Wrocławiu ${ }^{34}$. To już było po śmierci jego syna ${ }^{35}$, po wydaniu poematu o jego śmierci ${ }^{36}$. Zostałem uprzedzony przez wydawców, że absolutnie nie wolno o to pytać. On sam chciał. Powiedział, że było tak super na spotkaniu, że się jakoś otworzył. Mówił po hebrajsku, Michał Sobelman tłumaczył, ja zadawałem pytania. Poczuł się dobrze i sam zaczął mówić o synu. Gdy idzie o Grossmana, lubię trzy jego książki.

\section{J.B.: A które poza Ajen erekh-ahawah?}

P.P.: Ajen erekh-ahawah mi się nie podoba. Tam gdzie kończy się kraj, czyli Isza Borachat Mibesora, to najważniejsza książka o współczesnym Izraelu. Moim zdaniem wybitna powieść.

${ }^{32}$ Mowa o Ore’ah natah la-lun (1939), czyli „Gość na noc”, powieści nietłumaczonej na język polski.

${ }^{33}$ Nawiązanie oczywiście do sfilmowanej powieści autobiograficznej Sipur al ahawa we-choszech (2002), czyli Opowieści o miłości i mroku (Muza, 2005) Amosa Oza.

${ }^{34}$ Mowa o spotkaniu z pisarzem podczas wrocławskiego Bruno Schulz. Festiwal 16 października $2014 \mathrm{r}$.

${ }^{35}$ Syn Grossmana - Uri, zginął 12 sierpnia 2006 r. od wybuchu rakiety przeciwczołgowej podczas operacji wojskowej w południowym Libanie.

${ }^{36}$ Chodzi o głośną powieść Isza Borachat Mibesora (2008; tłum. ang. To the End of the Land, 2010; pol. Tam, gdzie kończy się kraj, 2013), która w dużej mierze traktuje o utracie syna. 
B.K.: Kto ze mna pobiegnie - młodzieżowa powieść, o której pisałeś...

P.P.: Super, bo to jest po prostu Niziurski. Nie wiem, czy widzieliście ekraniza$\mathrm{cję}^{37}$. To jest przepiękny film i niezwykle smutna historia. Główną bohaterkę, siostrę, która wyciąga brata z narkotyków, gra przepiękna dwudziestolatka ${ }^{38}$. To był debiut, szykowała się wielka kariera filmowa. Później miała straszny wypadek samochodowy, który ją oszpecił. Przeszła wielomiesięczną rehabilitację, teraz jest aktorką radiową, która podkłada głos. Rozbłysła i zgasła. Film jest świeży, ładny. Tę powieść lubię. Lubię też „Uśmiech baranka”, według której także nakręcono film. Lata 60., Jerozolima, dzieciństwo głównego bohatera na jerozolimskim osiedlu, kłopoty z rodzicami, z dominującą matką, z ojcem zakochanym w sąsiadce, która jest artystką i nauczycielką ${ }^{39}$. Piękna ekranizacja, a powieść taka „polsko-rosyjska”, mało izraelska i w ogóle poniekąd diasporowa, ale nie o Zagładzie.

J.B.: Ale też ta ostatnia Soos Echad Nechnas L'bar, czyli „Wchodzi koń do baru” (2016).

P.P.: A nie, to mi się nie podobało.

J.B.: Dobrze, a dlaczego Ajen erekh-ahawah (Patrz pod: Miłość) nie?

P.P.: Wydaje mi się, że jest to nieudany eksperyment. Ta część schulzowska, o rybie jest bardzo niedobra. Nie wiem, czytałem to dawno i jakoś mi się zupełnie nie podobało.

B.K.: Gorsza jest trzecia część...

P.P.: Ten zakład z esesmanem? To jest druga czy trzecia?

B.K.: Trzecia, ta o dziadku.

P.P.: Ten słownik postaci jest całkiem fajny, czyli losy bohaterów, czwarta część, zapętlona. Ale zakład obozowy jest makabryczny. Nie wiem, rozłazi mu się to. Próbował coś zrobić. Mam wrażenie, że chciał koniecznie napisać książkę o Zagładzie, jakby wisiało nad nim jakieś fatum. Tymczasem Grossman nie jest

${ }^{37}$ Powieść Miszehu laruts ito (2000) została sfilmowana w 2006 r. w reżyserii Odeda Davidoffa.

${ }^{38}$ Mowa o Bar Belfer, która grała Tamar. 23 marca 2010 r. aktorka została potrącona przez samochód, kiedy wysiadała ze swojego auta, które uległo awarii.

${ }^{39}$ Chodzi o powieść (1983) i film Hiuch ha-Gdi (1986) w reżyserii Shimona Dotana. Tytuł można przetłumaczyć jako „Uśmiech baranka”. Książka nie ukazała się po polsku. 
pisarzem Zagłady. Jest pisarzem izraelskim. Jest stamtąd. Rozmawiałem z nim na ten temat. Przywiózł kiedyś do Polski swojego ojca, który był z Dynowa, chasydzkiego miasteczka na Podkarpaciu. Grossman chciałby być stąd, ale już nie jest. Oz jest bardzo izraelski, ale jednocześnie europejski, natomiast Grossman jest bardziej izraelski, hebrajski. Bardziej niż Oz, który wciąż puszcza oko do czytelników, że wszyscy jesteśmy z Czechowa. Okazuje się, że nie zawsze jesteśmy tymi, którymi byśmy chcieli być.

J.B.: To jest też ciekawe, że Momik - pierwsza część Patrz pod: Miłość - funkcjonuje jako osobna książka. Jest wydawany oddzielnie, zresztą w kanonie lektur także figuruje jako osobna pozycja. Jest tylko Momik, cała reszta nie. Być może to lepiej, bo wydaje mi się, że to najlepsza część z tych trzech. Niezależnie jednak od wartości literackiej tej książki ona zbudowała w Izraelu dość mocny paradygmat literatury zagładowej. Jak myślisz, dlaczego?

P.P.: Nie wiem, dlaczego on, a nie na przykład Appelfeld. Może Appelfeld jest zbyt diasporowy...

J.B.: Wydaje mi się, że te wizje Grossmana są już przefiltrowane przez izraelską, zbiorową wyobraźnię i w pewnym sensie są z nią bardziej koherentne. I być może przez to łatwiej się adaptują, a Appelfeld porusza się gdzieś na marginesach.

P.P.: Wolę zdecydowanie Appelfelda jako pisarza. Na przykład Tzili (1982) rzecz o Zagładzie, czy Drogi żelazne. Ale i jego późną powieść Laisz, o przedziwnej wyprawie grupy żydowskich żebraków, złodziei, handlarzy i bezdomnych do Ziemi Izraela. Piękna książka, utrzymana w konwencji cudownej opowieści pielgrzymkowej, ale bez cudów i pomocy Opatrzności.

J.B.: Na przykład jego powieść Polin, erec jeruka (2005), czyli „Polska, zielony kraj”, jest akurat wyjątkowo mało udana. Wiązałam z nią duże nadzieje.

P.P.: Wiesz, on z kolei bardzo dużo tego naprodukował.

J.B.: Sześćdziesiąt sześć czy siedem nawet w tej chwili...

P.P.: Kiedyś miałem ambicję, by przeczytać wszystko Appelfelda - zdaje się, że tego nie zrobię. Ale kilka $\mathrm{z}$ tych książek jest ładnych.

J.B.: Badenheim na przykład.

P.P.: Badenheim jest niesamowitą książką. Prezagładową właściwie. Można ją czytać jako powieść syjonistyczną w tym sensie, że: „a mówiłem wam, macie 
uciekać, byliście głupi”, a jednocześnie taka historia o załamywaniu się pewnego ładu, ślepocie.

\section{J.B.: A myślałeś kiedyś o Badenheim w kontekście Twojego Pensjonatu ${ }^{40}$ ?}

P.P.: W tym kontekście nie, ale ja w ogóle lubię literaturę - że tak powiem uzdrowiskową.

B.K.: A co sądzisz o Zagładzie (1987) Piotra Szewca? Swego czasu czytałem te powieści razem, tzn. Zagładę i Badenheim.

P.P.: Chyba nie czytałem Zagłady Szewca.

B.K.: Jest oparta na takim samym pomyśle, tylko wcześniejsza. Również jest prezagładowa. Akcja dzieje się w Zamościu na chwilę przed Holokaustem.

P.P.: Aaa, pamiętam, że streszczałeś ją w swojej książce ${ }^{41}$.

J.B.: A propos tej diasporowości Appelfelda to Yigal Schwartz ${ }^{42}$ wysuwa ciekawą hipotezę, że tym, co naprawdę boli Izrael w twórczości Appelfelda, nie jest jej diasporowość, tylko to, że okazuje się, iż diasporowość Appelfelda doskonale opisuje izraelskie realia. Uwypukla wszystkie izraelskie bolączki i przez to one się stają jeszcze bardziej dojmujące ${ }^{43}$. Jeszcze nie wiem, czy temu ufam, ale coś w tym może być. Wydaje mi się, że ewidentnie izraelskie społeczeństwo coś bardzo mocno bolało w tym podejściu.

B.K.: Izrael w ogóle miał problem z literaturą diaspory. Dowodem na to są perypetie „naszych” pisarek polskojęzycznych, na przykład Idy Fink, która nagle została odkryta. Kiedy wydała po raz pierwszy Skrawek czasu (1973), toczyła się akurat wojna Jom Kipur, a zbiór został fatalnie przetłumaczony, więc gdzieś zniknął. Sposób, w jaki ona była odkrywana w latach 70., jest wymowny. Chodzi o to, że krytycy w Izraelu czuli, że coś by trzeba z jej twórczością zrobić, bo autorka zaczęła zbierać poważne nagrody za granicą, ale nie do końca wiedzieli co, nie wiedzieli, jak tę twórczość „ugryźćc.

40 Pensjonat to debiutancka powieść Piotra Pazińskiego z 2009 r.

${ }^{41}$ Chodzi o: B. Krupa: Opowiedzieć Zagładę. Polska proza i historiografia wobec Holokaustu. Kraków 2013.

42 Yigal Schwartz (ur. 1954) - krytyk i literaturoznawca, autor kilkunastu książek naukowych i twórca „Heksherim”: Instytutu Badawczego Żydowskiej i Izraelskiej Literatury i Kultury na Uniwersytecie Ben-Guriona.

43 Mowa o eseju Y. Schwartza z tomu Ma’amin bli knesija („Wierzący bez świątyni”; Dvir Publishing House, 2009). 
J.B.: Wydaje mi się, że jeszcze à propos tego, dlaczego Grossman się wpisał, a Appelfeld zawsze pozostawał w jakimś stopniu marginalny, później został doceniony, ale poniewczasie, to być może dlatego, że Grossman wpisał się czasowo w boom literatury zagładowej. Może nie tyle się wpisał, ile go współtworzył.

P.P.: Był pionierem.

J.B.: Właśnie, wpisał się w tę całą falę drugiego pokolenia, a jednocześnie może dał język późniejszym twórcom.

P.P.: Nie wiem, może powinienem go jeszcze raz przeczytać.

B.K.: W ocenach tej powieści jesteśmy zgodni, zdaje się.

J.B.: Przyznam się, że gdy po raz pierwszy czytałam Patrz pod: Miłość w przekładzie Magdaleny Sommer, a było to jakoś na początku studiów, to dałam się złapać. Na początku ten koncept mi się nawet podobał, ale być może dlatego, że to trochę na mnie podziałało paradygmatycznie.

B.K.: Trzeba „mordować” swoich mistrzów. Tak samo czytałem Umschlagplatz (1988) Jarosława Rymkiewicza. Na początku było takie wow.

P.P.: A potem co?

B.K.: Nie nazwałbym oczywiście Rymkiewicza symbolicznym „ojcem”, którego trzeba zamordować, ale rzeczywiście przy pierwszej lekturze...

P.P.: Robi wrażenie, no nie? A potem się ukazują takie teksty, które sprawiają, że przestajesz wierzyć.

B.K.: Dobrze, ale wracam do pierwotnego pytania. Skąd ten unik? Dlaczego bardziej interesuje Cię druga alija, dlaczego raczej tworzenie państwa, a w Zagładę „po izraelsku” nie wchodzisz?

P.P.: Hm, to pewnie będzie pytanie o mnie, tzn. co ja stamtąd biorę. Być może dość wygodnie to sobie w głowie podzieliłem, że Zagłada należy do diaspory, a Izrael jest od tego wolny. W literaturze hebrajskiej interesowało mnie budowanie czy prebudowanie państwa, czyli to, co tam się dzieje, powiedzmy, od lat 20. i 30. Dlatego lubię tamtą literaturę, bo ona mnie na różne sposoby ciekawiła. Jako proza dokumentarna - jak to wyglądało, tam kiedyś. Jak się tworzyło coś zupełnie nowego. Zagłada mi przeszkadzała, bo była z zupełnie innego porządku. 
J.B.: Jednak mimo tego wszystkiego, o czym mówiliśmy, że literatura hebrajska milczała, była zajęta innymi sprawami, są konteksty, w których Zagłada okazywała się jakoś funkcjonalna. Nie w prostym przełożeniu oczywiście. Przecież mamy teksty Chaima Guriego ${ }^{44}$, Lei Goldberg ${ }^{45} \ldots$

P.P.: Mamy Ka-Tzetnika ${ }^{46} \ldots$

J.B.: Ka-Tzetnik to jest jeszcze trochę inna bajka, bo on jednak przeżył Zagładę. Wprawdzie nie możemy być pewni jak i gdzie, ale przeżył.

P.P.: Mamy Jehudę Amichaia, cały jego problem z niemieckością.

J.B.: A więc w takim kontekście, jak powstawało państwo, Zagłada nie jest czynnikiem pozbawionym znaczenia.

P.P.: To może zacznę od jeszcze innego końca. Dość dużo czasu spędziłem w Jerozolimie, w którą się jakoś „wbiłem”, i do dziś bardzo ją lubię. To była taka Jerozolima końca wieku XIX do początków państwa. To znaczy taka Jerozolima końca panowania tureckiego, Mandatu Palestyny, pierwszej aliji. Włóczyłem się całymi godzinami po Mea Szearim, Nachalat Sziwa. Mieszkałem dłuższy czas na Rechawii, która była dzielnicą $\mathrm{z}$ lat 30. Jeśli coś mnie fascynowało, to naprawdę ten okres przedpaństwowy. I jak odkryłem to u Agnona oraz Brennera, w takiej pięknej powieści, która się dzieje w Jerozolimie - Szikol We-Kiszalon ${ }^{47}$, będącej wspaniałą opowieścią o zapyziałej, podupadłej, właściwie upadłej Jerozolimie, to mnie to zawsze najbardziej ciekawiło. Interesowały mnie osady pionierów, siedzących po kibucach, po pierwszych miasteczkach, typu Mazkeret Batja, Rosz Pina, Petach Tikwa. Te rzeczy mnie bardziej inspirowały niż to, co było później. Lubię architekturę z tego okresu, na przykład w Jerozolimie. Może to było jakieś antidotum, odtrutka. Bardziej fascynowały mnie tam antykwariaty, księgarnie $\mathrm{i}$ te stare mieszkania zapchane książkami. Inne, jakby z wyminiętą Zagładą. To bardzo dziwne, bo czasami się opowiada, że Izrael jest tak prze-

${ }^{44}$ Chaim Guri (1923-2018) - izraelski poeta, pisarz, dziennikarz i dokumentalista. Urodzony w Tel Awiwie jako Haim Gurfinkel. Brał udział w wojnie o niepodległość, studiował literaturę na Uniwersytecie Hebrajskim i Sorbonie. Zyskał sławę jako dziennikarz relacjonujący proces Eichmanna (1961).

${ }^{45}$ Lea Goldberg (1911-1970) - hebrajskojęzyczna poetka, pisarka, autorka sztuk i tłumaczka. Urodzona w Królewcu, studiowała w Berlinie. W 1935 r. osiedliła się w Tel Awiwie, przyłączając się do grupy poetyckiej Jachdaw („Razem”).

${ }^{46}$ Ka-Tzetnik, Jehiel Dinur (1909-2001) - ur. jako Jehiel Feiner w Sosnowcu, więzień Auschwitz. W 1945 r. zamieszkał w Izraelu i posługiwał się pseudonimem Ka-Tzetnik 135633 (numer obozowy). Najsłynniejszą jego książką jest Dom lalek (1956).

${ }^{47}$ Szikol We-Kiszalon - powieść Brennera z 1920 r., której tytuł można przetłumaczyć jako „Osierocenie i klęska”. 
siąknięty Holokaustem. A mnie interesowały rzeczy wcześniejsze, boczne. No i Jerozolima jako taka. Naprawdę, całkiem szczerze, uważam jerozolimską ir atika, Stare Miasto za murami za najbardziej niesamowite miejsce na Ziemi. Byłem na Starym Mieście setki razy i każdorazowo jest to dla mnie niezwykle intensywne przeżycie. Mogę tam błąkać się godzinami. Jerozolima wciąż mnie fascynuje. Bardzo lubię Tel Awiw, lubię jeździć po kraju, ale zawsze wracam do Jerozolimy. A ona, jakby to kiczowato nie brzmiało, jest wieczna. A jednocześnie porozbijana jak skorupy w luriańskim micie. Więc szukałem i szukam literatury jerozolimskiej: gorzkiego świeckiego Brennera, mistycznego Agnona, głęboko religijnej Zeldy Schneerson, europejskiego Oza, sefardyjskiego Jehoszui, magicznego Dawida Szachara, bardzo ciekawego współczesnego Chaima Be’era, autora pięknej powieści Nocot, „Pióra”.

B.K.: Zapytam od drugiej strony. Jak na tym tle ma się literatura polska? W niej też nie śledzisz tematyki zagładowej?

P.P.: Właśnie wręcz przeciwnie! Widocznie zrobiłem sobie w głowie taki wygodny podział. Dla mnie Izrael to nie była Zagłada. Izrael to były od dzieciństwa znaczki pocztowe $\mathrm{z}$ hebrajskimi literkami, owoce, krajobrazy. Pamiętam taką Jerozolimę, którą odkrywałem jeszcze jako nastolatek, zupełnie niesamowitą, inną niż teraz.

B.K.: A kiedy pierwszy raz w niej byłeś?

P.P.: Miało to miejsce, umówmy się, przynajmniej ćwierć wieku temu. To było inne miasto. Dużo bardziej kameralne i takie na ludzką miarę. Nie było tych wszystkich autostrad, blokowisk. Więc jak później przeczytałem w Sipur al ahawa we-choszech, czyli w Opowieści o miłości i mroku, o drodze z Kerem Awraham (czyli jednej z subdzielnic tego, co się dzisiaj nazywa Mea Szearim, kompleksu dzielnic ortodoksyjnych na północ od ulicy Jaffo), jak oni idą na Talpiot, do wuja Josefa, to całą tę drogę znam na pamięć. I to jest właśnie dla mnie literatura izraelska, a nie Grossman i jego opowieści o Zagładzie. Dla mnie ucieleśnieniem literatury zagładowej jest Kacenelson i jego Pieśn o zamordowanym żydowskim narodzie. Została wydana chyba na początku lat 80 . i leżała w domu, mogłem po nią sięgnąć jako dziecko. I te wszystkie takie ŻIH-owskie książki. Archiwum Ringelbluma. Upiorny Dziennik Adama Czerniakowa. To jest dla mnie Zagłada. Książki Ruty Sakowskiej, Bernarda Marka, kolejne tomy powstania w getcie, stare prace o zbrodniach hitlerowskich.

J.B.: To jest ciekawe, co mówisz, bo dość dobrze pokrywa się z taką cechą literatury hebrajskiej, zagładowej, która jest dla mnie dojmująco wyraźna. To, co określamy jako tę literaturę, to są teksty, które zwykle nie opisują samej Zagłady, 
ale opisują to, co działo się krótko po albo przed, natomiast same świadectwa pozostawały poza.

B.K.: One nie mogły być hebrajskie. To nie był język do wyrażania Zagłady.

P.P.: Dziennik Chaima Kaplana byłby tutaj wyjątkiem. Tyle że on powstaje tu, w Warszawie i ginie w Warszawie.

J.B.: Na tym też polegała wyjątkowość Kaniuka i jego Adam Ben Kelew (1971), który zawiera te obrazy, i Ka-Tzetnik się wyróżnia na tym tle. Chociaż uważam, że należy podkreślać fakt, że Ka-Tzetnik nie pisał po hebrajsku, tylko żona go tłumaczyła i dopiero wtedy tekst był wydawany.

B.K.: Tak, to był autoryzowany przekład, w ten sposób dochodzimy zresztą do problemu autorstwa w ogóle.

J.B.: W latach 60. te trzy książki, dalsze, Ka-Tzetnik już pisał po hebrajsku, ale tę trylogię rodziny żydowskiej w XX wieku, czyli Salamandre (1946), Beit habubot (1953) i Piepela (1961) - nie.

P.P.: Właśnie, język jidysz był językiem Zagłady, szczątków tego, co tutaj zostało, w którym o tym mówiono, w którym o tym pisano. Nawet krojem czcionek się różniły. Do dzisiaj mam to przed oczami. Książki wydawane wtedy w Jidysz-Buch, które leżały w domu, różniły się od czcionki hebrajskiej ze znaczków pocztowych, listów czy druków izraelskich. Do dzisiaj to poznam. To jest skądinąd sprawa znana, bo czcionki często denotują przynależność polityczną czy ideową.

Być może dlatego, że Izrael to była bardzo duża, religijna rodzina u mnie, ale też część rodziny świeckiej - albo kibuc, albo Jerozolima. Te różne odłamy mojej rodziny wyjechały wcześniej, w latach 30., one nie przeżyły tutaj Zagłady. Ocaleńcy byli tu i z kolei mówili po polsku. Dlatego to się tak podzieliło. Tam był świat hebrajski i wydawało mi się, że on jest odseparowany od Zagłady. Oczywiście zostałem zaprowadzony do Jad Waszem, starego Jad Waszem, które nie mieściło się jeszcze $\mathrm{w}$ tym gigantycznym budynku zakopanym $\mathrm{w}$ ziemi. To był wtedy taki pawilon. Wszystkie rzeczy grzecznie obejrzałem, ale bardziej interesowało mnie Muzeum Hagany w Tel Awiwie. Pamiętam jakieś armaty, limuzyny, czołgi.

J.B.: Odnośnie do Jerozolimy i Zagłady - pewnie byliście w Martef ha-Szo’a (Piwnica Zagłady) na Starym Mieście?

B.K.: Opowiadałaś o tym muzeum, a ja je zupełnie przegapiłem. 
P.P.: Nie, nie byłem.

J.B.: Jest to niesamowite miejsce. Sądzę, że ono się nie zmieniło zupełnie od 1949 roku, kiedy powstało. Wszystko tam stoi tak samo. Trudno tam trafić, jeśli się nie wie o tym miejscu. To jest piwnica, w której ściany są wyłożone tablicami upamiętniającymi miasteczka, gdzie mieszkali Żydzi, później zamordowani. Są też bardzo niepokojące rzeczy. Eksponaty nie są podpisane. Nie ma żadnego komentarza, żadnej narracji, co w dobie muzeów narracyjnych jest dość ciekawe. Natomiast stoi tam gablota, w której znajdują się kostki mydła, ułożone jedna obok drugiej. Podejrzewam, że intencja jest taka, iż w głowie mają otwierać się wszystkie klisze i automatycznie zakładamy, o co tutaj może chodzić. To niesamowite, że w Jerozolimie funkcjonuje takie schowane miejsce, które przecież istnieje tak długo, jak to państwo.

P.P.: Z drugiej strony jest też Jad Waszem, które zajmuje całe wzgórze.

J.B.: Rzeczywiście, Jad Waszem jest miejscem, które widzisz. Co prawda lepiej widzisz Górę Herzla, co także jest dość znaczące.

B.K.: Poruszyłaś przypadkiem ciekawy wątek. Będę jednak z uporem maniaka drążył temat unikania, bo napisałeś w mailu, że to jest „świadome unikanie”, więc tak się zastanawiam, tym bardziej że wspomniałeś o dzieciństwie, Niziurskim.

P.P.: Wydaje mi się, że trochę mi z tego zostało.

B.K.: Właśnie, czy nie jest trochę tak, że boisz się to skazić. Tak jak to muzeum, które gdzieś na tej starówce tkwi, w piwnicy, jest takim punktem, które mogłoby ten Twój Izrael wywrócić. Przepraszam, że dokonuję ad hoc takiej interpretacji.

P.P.: Może tak jest, że chciałbym, żeby to pozostało poza.

B.K.: Na przykład Nienackiego nie można czytać po latach. Popełniam ten błąd i czytam całego Pana Samochodzika jeszcze raz. Mizoginia wyziera tam z każdej strony. Z Niziurskiego o dziwo całkiem nieźle bronią się powieści socrealistyczne, jak Księga urwisów (1954), ale też i późniejszy Klub włóczykijów (1970), który czytałem kilkanaście razy. Zasadniczo pilnujemy swojej przestrzeni i staramy się nie czytać tego inaczej.

J.B.: Z tego powodu przestałam na przykład chodzić do opery.

B.K.: Jakoś pielęgnujemy tę iluzję. Próbuję się głośno zastanawiać nad mechanizmem wspomnianego uniku. 
P.P.: Zgadzam się, bo stykam się z tym nieustannie. Izrael był obecny w moim życiu prawie zawsze. Najpierw był jako coś tam, potem coś, do czego się jeździ. Może dlatego ten zestaw jest wciąż dziecięcy w moim przypadku. Pomarańcze Jaffa, przyprawy i koncentraty spożywcze Osem, kefir i sery z Tnuwy, stare, wycofane $\mathrm{z}$ obiegu banknoty jednoszeklowe, pewne smaki, pewne symbole.

J.B.: Z drugiej strony Twoje teksty są ufundowane na różnych dziecięcych wspomnieniach. Przecież Pensjonat jest cały na nich zbudowany.

P.P.: No tak, ale to było tu.

J.B.: Pamiętam też, jak na spotkaniu, które było w Poznaniu ${ }^{48}$, ale mówiłeś również o tym w wywiadach, wspominałeś, że być może inaczej wyglądałaby Twoja proza, gdybyś spędzał wakacje wśród łąk i lasów z gromadką dzieci, ale ty spędzałeś je tak.

P.P.: Na pewno tak by było.

J.B.: Czyli jest to jednak fragment dzieciństwa, którego nie da się odciąć?

P.P.: Ale on jest tutejszy, a nie izraelski. To jest najprostsza odpowiedź.

B.K.: Coraz bardziej zbliżamy się do paradoksalnego wniosku, że Izrael się nie nadaje do pisania o Zagładzie.

P.P.: Ja mam na temat Izraela mnóstwo różnych, widmowych przemyśleń i emocji.

B.K.: Ale niezwiązanych z Zagładą?

P.P.: Niezwiązanych. Całe lata się zastanawiałem, czy tam zamieszkać, czy nie, czy bym się tam dopasował, czy nie. Zastanawiałem się, co by było, gdybym się tam urodził. Co bym pisał po hebrajsku? Do dzisiaj się nad tym zastanawiam.

B.K.: Zamieszkałbym od razu, gdyby była taka możliwość.

P.P.: Czy mógłbym na przykład zamieszkać i się bardzo rozczarować, być właściwie w kontrze? Czy bym się w tym zatopił? Mam niezmiernie dużo przemyśleń, coraz więcej. Kiedyś tam jeździłem bez przerwy, teraz jeżdżę rzadziej. Bywałem

${ }^{48}$ Mowa o spotkaniu autorskim z Piotrem Pazińskim, które odbyło się 11 października 2017 r. w Domu Spotkań Otwarta Żydowska w Poznaniu. 
tam trzy razy do roku i to było bardzo intensywne. Moje przemyślenia nigdy nie były jednak specjalnie holokaustowe, nic na to nie poradzę. Oczywiście potem interesowała mnie bardzo izraelska polityka. Jeśli się bez przerwy o niej mówiło tam i bez przerwy mówiło się o niej tutaj.

\section{B.K.: W domu?}

P.P.: $\mathrm{W}$ domu, ale też tam wszyscy mówili o polityce. Wszyscy Izraelczycy mówią o polityce. Wiem, w związku z tym mnie strasznie interesowały te czasy etosowe! Budowanie, tworzenie, czyli - możecie mnie docisnąć - rzeczy pozytywne. Fascynowały mnie początki państwa, tym bardziej że stykałem się ze świadkami historii, poznałem wielu budowniczych Kraju. Historia sukcesu. Czy ja nie chciałem jej sobie zepsuć?

B.K.: To jest jednak sukces podminowywany różnymi takimi Tomami Segevami ${ }^{49}$.

P.P.: To prawda, tylko ja najintensywniej tam bywałem w latach 90 . To był trochę inny okres, inny kraj, więc i inny sukces. Nie umiem odpowiedzieć, dlaczego Zagłada nie tam, ale tak faktycznie było. Mnie nawet nie dziwiły te miejsca. Byłem w kibucu Lochame ha-Geta'ot ${ }^{50}$, w Jad Waszem wiele razy, ale coś mi tam zawsze nie pasowało. To było takie dziwne, nie pasowało do tamtego krajobrazu.

J.B.: Zaczęłam się zastanawiać nad jedną rzeczą. Używa się takiego sformułowania - mówi się, że „Izrael jest nasiąknięty Zagładą”, a jednak okazuje się, że wcale nie. Czy nie jest tak, że Zagłada zawsze była w Izraelu czymś, co trzeba było...

B.K.: Aplikować czy jakoś tak doklejać. Żyli tam ludzie, którzy nie chcieli na ten temat mówić lub pisali w swoich małych kręgach, polskojęzycznych czy jakichś innych, a średnio to pasowało do ogółu.

P.P.: Czy Zagłada była doklejana? Chyba nie, ona była jednak częścią ideologii.

J.B.: Właśnie, w tym sensie była doklejana.

B.K.: Była częścią ideologii, o to chodzi. Nie wynikała naturalnie z potrzeb wyrażenia tego, co przeżyliśmy.

${ }^{49}$ Tom Segev (ur. 1945) - izraelski historyk i dziennikarz. Związany z ruchem Izraelskich Nowych Historyków, podważających wiele utartych, państwowych narracji. W książce Siódmy milion (1993, pol. 2012) opisuje wpływ, jaki wywarła Zagłada na politykę w Izraelu.

${ }^{50}$ Lochame ha-Geta’ot - kibuc w północnym Izraelu, gdzie mieści się Muzeum Bojowników Getta. 
J.B.: Jeśli porównamy, to w Polsce ona nie była częścią ideologii, tylko czymś immanentnie obecnym.

B.K.: Czymś, co wydobywa się z każdego kamienia.

J.B.: W Izraelu tak nie jest. Kiedyś czytałam taki kuriozalny tekst o podróżach w izraelskiej literaturze. Był tam rozdział o wyjazdach do Polski. Autorka analizowała przywołane już przez Ciebie opowiadanie Kereta o bucie. Przez pryzmat wyprawy do Polski porównywała klasową wycieczkę, którą on opisuje, do domu Żydów z Wołynia. Mam takie poczucie bardzo sztucznego aplikowania tego do izraelskiej rzeczywistości.

B.K.: Też mam takie wrażenie, gdy śledzę recepcję Idy Fink. To był taki efekt paniki. Kiedy ona się pojawia - ktoś, kto żył od 1957 roku pod naszym bokiem, cały czas pisał, a myśmy to jakoś przegapili, odrzucaliśmy, bo mówiliśmy, że tak się nie pisze o Zagładzie (jest taka głośna historia, że pisarce odmówiono publikacji z takiego właśnie powodu, kiedy zaniosła opowiadania do wydawnictwa w latach 60.) - nagle w połowie lat 80 . odkrywa się, że napisała coś ważnego.

J.B.: Jednocześnie teraz również widać ten rozkład przestrzenny i to, jak on jest tematyzowany. Jednak Izrael jest tym miejscem życia, a Zagładę zostawia się w Polsce.

P.P.: Niekiedy się niestety z tym zgadzam. To oczywiście będzie bardzo nieładne i niepoprawne politycznie, co teraz powiem, ale ja czasami tak sobie myślę, że tam jest życie, a tu już jakby nie-życie. Wiem, że to gol do własnej bramki.

\section{J.B.: Zależy, czym to motywujesz?}

B.K.: I kim chcesz być. Strażnikiem grobów i tu zostać?

P.P.: Cały czas poruszamy się w tej opozycji - tu strażnik grobów, tam odżywasz, jesteś pionierem. Nawet nie osadnikiem, jakimś tam faszystą.

J.B.: To się wszystko zasadza na schemacie przestrzennym, który się ujawnia wszędzie. Widzisz to w Jad Waszem, gdzie masz część zagładową na dole, górę Herzla powyżej, widzisz to w piwnicy Szoa, do której musisz zejść, żeby zobaczyć tę wystawę. To ujawnia się w tylu miejscach, na tyle sposobów, a ten podział przestrzenny w dużej mierze organizuje też izraelską wyobraźnię, jeśli chodzi o kwestie Zagłady.

P.P.: Może powiem coś nieładnego, ale ja się tym nigdy nie czułem jakoś bardzo zgorszony. Rozumiem, że ma to różne drugie strony i odbywało się często 
kosztem ocaleńców, którzy tam później przyjechali. Gdzieś zasadniczo, w sensie takiego ruchu metafizycznego, rozumiem tę emocję zbiorową, nie postrzegam jej wyłącznie jako ideologii - od Szoa do odbudowy. Tylko że mnie ta odbudowa ciekawiła i wcześniej. Najbardziej interesowały mnie czasy jiszuwu. Jak doskonale wiecie, w Izraelu są różne definicje tego, co jest stare. Jerozolima jest stara, ruiny zamków krzyżowców są stare, meczety są stare, mnie interesowało to, co też się nazywa starym i pochodziło z końca XIX oraz pierwszej dekady XX wieku. Uwielbiam te wszystkie dzielnice z początku XX wieku. Może stąd, że to przesuwałem sobie wcześniej w głowie, estetycznie jakoś, tak to uporządkowałem. Wychowałem się jednak wśród opowieści części mojej rodziny, która przyjechała tam w latach 30., wymijając Zagładę, jak się tylko dało. Zresztą nie próbując poznać Polski, co charakterystyczne. Może dwie tylko osoby były potem tutaj. Znakomita większość tych ludzi nie była, nie widzieli Polski bez Żydów. Pamiętam jednego z moich wujów: prawdziwy izraelski rolnik. Facet z rękami jak bochny chleba. Spracowany, rumiany, wyglądał zupełnie inaczej niż wszyscy znani mi Żydzi. Zakładał kibuc od lat 20. To był Izraelczyk. Z kolei bardzo późno poznałem Izraelczyków, którzy byli ocaleńcami, więc to jest być może mój rozjazd mentalny.

Poznałem też bardzo wielu Polaków z aliji gomułkowskiej, ale większość z tych ludzi - umówmy się - nie wiem, czy można o nich powiedzieć, o osobach, które przeżyły w Uzbekistanie czy Kazachstanie, że są ocaleńcami. Tak jak moja najbliższa rodzina. Mam z tym problem, bo czy można o rodzicach czy dziadkach, którzy przeżyli w ten sposób, powiedzieć, że są ocaleńcami? Wydaje mi się, że w sensie takim mocnym - nie. Oni są wychodźcami, emigrantami, uchodźcami wojennymi czy kim tam chcecie, ale oni nie są ocaleńcami. Sądzę, że to jest bardzo poważna różnica antropologiczna, która nie dotyczy wyłącznie Izraela. Mówiąc najkrócej - ludzie, których znałem w Izraelu najwcześniej, nie byli ocaleńcami z Zagłady. Uważam, że ta dystynkcja jest ważna, również dla zrozumienia moich własnych wyborów. Dlaczego Izrael równa się życie, a tutaj nie. To jest już zresztą trochę inny temat. Czy większość polskich Żydów (pewnie osiemdziesiąt procent, które przeżyło drugą wojnę światową, z tych dziesięciu procent, które przeżyło w ogóle) ocalała w Azji Środkowej, w ZSRR - czy to są ocaleńcy? Kiedy bardzo głęboko zaglądam w świadomość własną, pamięć historyczną, antropologiczną moją czy mojej rodziny, to nie są ocaleńcy. Ocaleńcami są ludzie, którymi zajmuje się Mikołaj Grynberg. Którzy siedzieli w szafie, którzy przeszli przez obozy, przez getta, którzy potem zostali tutaj albo wyjechali.

Oczywiście nie jest tak, że tam z ocaleńcami w ogóle się nie stykałem. Nie wiem, czy widzieliście to kiedykolwiek w Izraelu. Już teraz, zdaje się, nie można tego zobaczyć, ale jeszcze wiele lat temu bywało tak, że na przykład: autobus stoi na przystanku, jest kolejka, pojazd zaczyna odjeżdżać i biegnie dziadek, który krzyczy: „Nicol ha Szo'a” - 'ocaleniec z Zagłady'. Słyszałem to wielokrotnie. 
B.K.: Poznałem tylko takiego dziadka, który przechodził codziennie obok mojego mieszkania w Talbiji. Kiedyś, gdy myłem rano samochód, zatrzymał się i zaczął mi opowiadać, że brał udział w wojnie o niepodległość i, jak podkreślał kilkukrotnie, jest z tego dumny. To inny rodzaj tożsamości, ale też „twardy”, będący powodem do dumy.

P.P.: Milchemet acma'ut [wojna o niepodległość] to jest co innego niż nicolot ha Szo’a.

J.B.: Tak, zresztą wśród nicolej ha Szo’a też jest hierarchia. Na przykład bardzo chętnie zabiera się na wycieczki tych, którzy byli w Auschwitz, a że ich już prawie nie ma, to bierze się innych. To jest straszne, ale tak to funkcjonuje.

P.P.: Hierarchie istniały zawsze. To nie jest tamtejsza specyfika. Mamy najwyżej do czynienia z zaprzęgnięciem hierarchii do czegoś nowego, do nowej polityki.

B.K.: W obozach też była hierarchia. Stare numery itp.

P.P.: I w związku z tym istnieją także hierarchie tych, którzy przeżyli. Pamiętam, dziesięć lat temu była taka dyskusja podczas kolejnej rocznicy w Sobiborze. Jeszcze poznałem tych uczestników powstania. Ostatnio przyjechało do Polski dwóch, którzy się strasznie nie lubili. Zaprzyjaźniłem się z panem Filipem Białowiczem, umarł rok temu. Na jakiejś uroczystości pojawił się człowiek, który uciekł $\mathrm{z}$ transportu. Powstał problem: czy to jest weteran Sobiboru, czy nie jest i czy wziąć go do oficjalnych uroczystości.

B.K.: To materiał na świetne opowiadanie.

J.B.: Kojarzycie taki zbiór nowel Nathana Englandera What we talk about when we talk about Anna Frank (2012)? Tam jest anegdota: jeden $\mathrm{z}$ bohaterów idzie ze swoim ojcem na basen czy siłownię, już teraz nie pamiętam. Ojciec zawiązuje sobie buty, a obok niego siedzi inny stary mężczyzna. Syn dostrzega, że obaj mają na rękach wytatuowane numery jeden po drugim, i mówi: „Tato, zobacz, macie kolejne numery". Starsi mężczyźni w ogóle się nie odzywają, nie reagują, w końcu się rozchodzą. Bohater mówi: „Tato, dlaczego nie reagowałeś? Przecież to coś musi znaczyć”, na co jego ojciec odpowiada: „Wiesz, co to znaczy? Że ten cham wciska się przed ludzi w kolejkę".

P.P.: To pewnie wykracza poza naszą rozmowę, ale istnieją rozmaite sposoby neutralizacji traumy, na przykład dowcipy w Auschwitz, przeniesienia... 
J.B.: Zastanawiam się, na ile to są tylko sposoby neutralizacji traumy, a na ile zapis tego, że ta rzeczywistość składała się również z najbardziej prozaicznych, banalnych rzeczy. One pozostają jej częścią.

P.P.: To na pewno, ale też bywały używane ex post. Wiemy z literatury obozowej, Prima Leviego czy Imre Kertésza, że tzw. niskie numery były prestiżowe. Głupio to dziś brzmi dla nas, ale musimy to przyjąć jako fakt socjologiczny. Jeśli w takim miejscu jak Birkenau tworzy się hierarchia prestiżu, to ona replikuje się później w cywilnym życiu. Czy to będzie Izrael, Polska, czy gdziekolwiek indziej. Ważne jest, czy siedzisz w pierwszym rzędzie na uroczystościach, czy w dziesiątym.

J.B.: To było także widać $\mathrm{w}$ fali oburzenia, że rodzina Witolda Pileckiego nie została zaproszona na rocznicę wyzwolenia Auschwitz, choć również żadna inna rodzina nie została zaproszona.

P.P.: Ale on jest tym więźniem ważniejszym. To samo jest z powstaniem w getcie warszawskim, gdzie powstańców podzielono tak naprawdę na trzy grupy ideologiczne: pojedynczego Marka Edelmana, Izraelczyków i osoby rozsiane po świecie. Później na różne sposoby ich rozgrywano, właściwie do końca.

B.K.: Do tego dochodzą rozmaite klasowe hierarchie. Na przykład Kazik Ratajzer także buduje swoisty mit „chłopaka z Czerniakowa”. O to też chciałem spytać. Wspominałeś o drugiej aliji, założycielach państwa, a ja chciałem spytać o czwartą - robotników i rzemieślników, którzy przybyli w latach 20.

P.P.: Poznałem kilku takich emigrantów. Żyli innym, hebrajskim życiem, bardzo izraelskim, jakby zupełnie nienaznaczeni Zagładą. To było fascynujące. Jeszcze tylko w Ameryce spotykałem takich ludzi. Ludzi SPRZED. Myślę, że akurat Izrael jest świetnym laboratorium hierarchii prestiżu. Jest tych hierarchii bardzo wiele, w czym przypomina trochę USA. Kto przyjechał wcześniej, ten lepszy. To jest absolutnie podstawowe kryterium.

J.B.: Są też wyjątki. Myślę o filmie Salah, po ze erec Israel ${ }^{51}$ o emigracji mizrachim. Dobrze jest w nim pokazana relacja pomiędzy przerzucaniem Żydów z Maroka i Jemenu na początku lat 60. a polską emigracją po 1968 roku. W filmie wykorzystano urzędowe pisma, w których jest napisane, że „przecież Polaków nie damy do ajara pituach na pustyni Negew. To są wykształceni ludzie”. Tutaj ta kategoria pierwszeństwa przestaje działać.

${ }^{51}$ Film Salah, tu jest ziemia Izraela w reżyserii Davida Deniego był dystrybuowany jako The Ancestral Sin (2017) („Grzech przodków”). Wywołał żywą reakcję w Izraelu. Dokument opowiada historię tzw. miast rozwijających się. Ujawnia metody, ideologię i okrutne praktyki organów ścigania oraz decydentów odpowiedzialnych za politykę „rozproszenia ludności” w pierwszych dwóch dekadach niepodległości. 
P.P.: Wszystko to pokazuje, że tych hierarchii jest bardzo wiele. Masz półpiśmiennego dzikusa przywiezionego w czasie operacji „Dywan” ${ }^{52}$ z Jemenu, który może mieszkać tylko gdzieś na Negewie i w zasadzie nie jest godzien czego innego. Doczekał się pierwszego ministra dopiero w latach 90., z drugiej strony szewc z Nalewek jest wyżej, bo jest aszkenazi, ale też niżej niż rodzina jemenicka z Jerozolimy. Niezwykle to jest trudne, te hierarchie się nakładają. Nie ma jednego porządku.

J.B.: Tak samo nie ma jednego układu pokoleń.

P.P.: W USA także możesz mieć osiemdziesiąt procent przodków emigrantów, ale jak masz jedną gałąź z Mayflower, to jesteś ktoś. Dość wysoko w hierarchii prestiżu stoją również sefaradim - Żydzi sefardyjscy. Inaczej nie mielibyśmy napisów na macewach, że ktoś był Sefardyjczykiem. Dotyczyło to w ogóle świata lewantyńskiego, bo to był właściwie ich świat. Aszkenazi pojawili się w XVIII wieku. Do XIX wieku był to nadal świat sefardyjski. To akurat udanie pokazuje w Panu Manim Jehoszua. Jerozolima to jest jakaś dziura pomiędzy Kairem a Konstantynopolem. Jemenickie rodziny z XIX wieku, obecnie właściciele kramów na bazarach, nadal cieszą się wielkim prestiżem.

B.K.: Wróćmy do Zagłady. Jak ona wypada na tym tle?

P.P.: $\mathrm{W}$ tym sensie Zagłada jest bardzo nisko prestiżowa.

B.K.: Może nie aż tak bardzo, ale faktycznie po ojcach założycielach.

P.P.: Nawet niżej, bo przed ojcami założycielami są tacy, którzy już tam wcześniej mieszkali. Stary jiszuw jest bardzo wysoko, podobnie wojsko.

J.B.: Mój przyjaciel, którego ojciec zginął w czasie wojny w Libanie, mówił mi, że widzi, jaki status ma ocaleństwo jego dziadków, a jaki śmierć ojca. Ten drugi stoi znacznie wyżej w hierarchii. W ogóle on sam czuje się pokrzywdzony przez kult, który rozwinął się wokół jego ojca. Zawsze był dzieckiem-maskotką, które można wystawić podczas Jom haCaHal (Dnia Sił Obronnych Izraela).

P.P.: To bardzo skomplikowane, bo na przykład hierarchia kibucowa w ogóle nie pokrywa się z finansową czy klasową. Kibuc z Degani to już zupełnie co innego. W pewnej mitologii, jak jesteś jednym z założycieli Nachalal, to jesteś na

52 Operacja „Dywan” - powszechnie używana nazwa dużej operacji wojskowej (oficjalna nazwa to „Operacja na Skrzydłach Orłów”). W jej ramach pomiędzy czerwcem 1949 a wrześniem 1950 r. przewieziono do Izraela 49000 Żydów z Jemenu i Adenu, ewakuowanych z powodu nasilających się prześladowań ze strony Arabów. 
topie. Z kolei gdzie indziej to nie ma znaczenia, bo dla Jerozolimczyków, którzy od dziesięciu pokoleń mieszkają na Starym Mieście, to nic nie znaczy. To jest procesualne. Jest pokolenie AK i pokolenie UB. Masz też żołnierzy wyklętych.

J.B.: Masz także ministra, który reprezentuje interesy tej grupy spod znaku żołnierzy wyklętych. Dokładnie to samo robi Miri Regew, która jako minister kultury wyznała publicznie, że nie czytała Czechowa. Jednocześnie bardzo mocno eksponuje, że jest w którymś pokoleniu mizrachijką. Uderza w tę strunę, że jest reprezentantką grupy wykluczonych, która wreszcie ma swojego przedstawiciela w establishmencie.

P.P.: Niestety za słabo znam socjologię współczesnego Izraela. Pamiętam, że w mojej gigantycznej rodzinie jakieś kilkanaście lat temu było jeszcze nie najgorzej w kwestii małżeństwa pomiędzy aszkenazi a mizrachim. To jeszcze nie był mezalians, zwłaszcza gdy panna młoda była superwykształcona, na przykład była inżynierem chemikiem, a pan młody był z jesziwy. Ale wcześniej powiedzenie o dziecku z klasy jednego z moich kuzynów, że co trzecie małżeństwo w jego rodzinie jest mieszane, już było degradujące. $W$ latach 60 . byłoby to w ogóle nie do pomyślenia. Teraz jest na porządku dziennym. Wielu moich kuzynów ma współmałżonków z Maroka, Iraku, Persji.

B.K.: Jeszcze oddzielnym tematem jest coś, co moglibyśmy nazwać Zagładą $\mathrm{w}$ imaginarium kultury izraelskiej, przez analogię do badań grupy z Instytutu Kultury Polskiej ${ }^{53}$. Myślę o przeniesieniu takiego projektu na teren izraelski.

P.P.: To imaginarium jest w Izraelu bardzo bogate. Od politycznego: druty, mur, granica, getto żydowskie, getto palestyńskie. To w zasadzie działa tam niemal wyłącznie na poziomie imaginarium. Nie ma krajobrazu, tej fizyczności.

B.K.: W Izraelu te hasła nie miałyby bliskiego desygnatu, namacalnego konkretu.

J.B.: $\mathrm{W}$ zasadzie to ułatwia takie procesy imaginaryjne, tworzenie form abstrakcyjnych, oderwanych w kontekście tej przestrzeni.

P.P.: Faktycznie można by ułożyć całą, odmienną od polskiej listę takich haseł.

B.K.: To pomysł na duży, międzynarodowy projekt.

${ }_{53}$ Zob. Ślady Holokaustu w imaginarium kultury polskiej. Red. J. KowalsKa-Leder, P. DoBrosielski, I. Kurz, M. SzPakowska. Warszawa 2017. 
P.P.: Tylko wtedy znów by wszedł język angielski. Mówiłem to na jakiejś konferencji. To swoisty paradoks - język, którym mówił może jeden promil ofiar Zagłady, stał się dominującym repozytorium tego doświadczenia. Angielski jest jakimś zupełnie niepotrzebnym pośrednikiem, który wtedy nie funkcjonował. Projekt hebrajsko-jidyszowo-polski dałby się zrobić.

J.B.: Myślałam też o tym w kontekście topiki Zagłady, czyli idei, której dotyczył na przykład drugi numer „Narracji o Zagładzie”, z 2016 roku. Jest tam tekst Sławomira Buryły ${ }^{54}, \mathrm{z}$ którym nie do końca się zgadzam. Autor zawarł w nim tezę, że największym repozytorium topiki zagładowej jest literatura polska. Wtedy pomyślałam sobie o literaturze hebrajskiej.

P.P.: Przede wszystkim o jidyszowej! Wielu polskich badaczy nie ma jednak językowych narzędzi, by czytać te teksty. Topika judajska to szkoła lubelska Władysława Panasa ${ }^{55}$.

B.K.: Wiele osób dochodziło do tematu z zupełnie różnych stron. Poniekąd ja też jestem taką osobą, bo zaczęło się od anglojęzycznej teorii historiografii. Jednak w języku polskim rzeczywiście powstało chyba najwięcej tekstów na temat Zagłady.

J.B.: Nie wiem, czy takie analizy ilościowe są adekwatne.

P.P.: Najlepiej byłoby znaleźć kogoś, kto operuje tymi wszystkimi językami. Jeśli chodzi o kwestie posttraumy, to pewnie język polski faktycznie byłby najbogatszy, ale świadectwa w jidysz są bardzo ważne. Na przykład archiwum Ringelbluma jest przeważnie jidyszowe. Oni, nawet gdy piszą po polsku, to myślą w jidysz. Także teksty węgierskie czy rumuńskie są istotne, choć grupa czerniowiecka, wokół Celana, posługiwała się głównie niemieckim. Z kolei badania na temat Zagłady są prowadzone głównie po angielsku, choć w latach 50. i 60. ważniejszy był nawet francuski. Swoją drogą trzeba przebadać fluktuację języków w samej Polsce. Do Marca 1968 masa rzeczy w kraju była jednak pisana po żydowsku, lata 70. są pod tym względem półmartwe. W latach 80 . na oryginalnych źródłach pracują pojedyncze osoby. Teraz następuje spore przyspieszenie, na przykład prac nad archiwum Ringelbluma, ale nie robią tego $\mathrm{z}$ oczywistych powodów

${ }^{54}$ Por. S. Bury£a: POCIĄGI ŚMIERCI - kilka uwag o konstrukcji hasła słownikowego. „Narracje o Zagładzie" 2016, nr 2, s. 63-71.

55 Władysław Panas (1947-2005) - historyk i teoretyk literatury, znawca twórczości B. Schulza, J. Czechowicza oraz wątków żydowskich w polskiej kulturze. Przez całe naukowe życie związany był z Katolickim Uniwersytetem Lubelskim. W poruszanym kontekście badacz był autorem niezwykle istotnego, pionierskiego szkicu Topika judajska $w$ literaturze polskiej XX wieku (w: W. Panas: Pismo i rana. Lublin 1996). 
native speakerzy, tylko osoby, dla których jidysz czy hebrajski jest językiem drugim, wyuczonym. Wydaje mi się, że tak samo było w Izraelu. Hebrajski był drugim językiem wobec jidysz, polskiego, niemieckiego. Na przykład Gershom Scholem ${ }^{56}$ pisze po hebrajsku okresami niemieckimi. Widać, że często przekłada mechanicznie, na przykład we wspomnieniach „Z Berlina do Jerozolimy” (1977) jego eseje hebrajskie są nie do czytania. Umówmy się jednak, że w ogóle nie ma czegoś takiego jak czysty hebrajski.

${ }^{56}$ Gershom Scholem (1897-1982) - filozof, badacz żydowskiego mistycyzmu, profesor Uniwersytetu Hebrajskiego w Jerozolimie. 